\title{
Young People's Narratives of Media and Identity
}

\author{
Mediagraphy as Identity Work in Upper Secondary School
}

\author{
Daniel Schofield \& Reijo Kupiainen
}

\begin{abstract}
The article explores how upper secondary students use the learning activity mediagraphy to reflect on their identity and on media as constraining and enabling factors in their social practice. In mediagraphy, the students research four generations of their own families, including themselves. They write a mediagraphy essay on the differences and similarities across the generations in media use and turning points in individuals' lives, in addition to societal and media-related developments. Data from student products and interviews are analysed through three "identity dilemmas" that any identity claim faces: the constant navigation between 1) continuity and change, 2) sameness and difference with regard to others, and 3) agency as "person-to-world" and "world-to-person". The findings suggest that mediagraphy is a type of identity work that can potentially help students develop an agentive identity in a time of insecurity, with rapidly shifting social and cultural conditions and increasing media density.
\end{abstract}

Keywords: mediagraphy, identity, agency, media use, media education, media literacy

\section{Introduction}

Young people's everyday lives are, at least in the media-saturated Western world, full of connections with various media devices and contents, from early morning to late evening - and sometimes also throughout the night. Media innovations continually make new types of social practice possible, but the media can also limit young people's social conduct, for example by determining where and how communication takes place, and especially by placing restrictions on use of time. Many everyday routines and rituals are developed alongside media use, and at the same time the media provide material for negotiating and defining social identities. As Stuart Hall (1996:4) puts it, identities are "constituted within, not outside representation", but also within different media practices and uses. Hence, in the context of media education, several scholars claim it has become crucial to reflect on one's own media use and one's relations to the media culture (Buckingham 2007; Burn \& Durran 2007; Jenkins 2007). Consequently, we need educational initiatives that can foster an understanding of how media-dominated everyday life plays into young people's identity (Gauntlett 2007; Kaare 2008; Lankshear \& Knobel 2007).

Mediagraphy has been used as a learning activity in media education to help students reflect on their own media relations (Schofield 2014; Vettenranta 2010b). Students are 
appointed as researchers and study four generations of their own families, including themselves. They write a mediagraphy essay on the differences and similarities across the family's generations in, e.g., development of the media, media use and turning points in individuals' lives, in addition to societal developments. Daily media use is an important starting point for the students' reflections (Schofield 2014). As such, the method renders everyday life visible, and sheds light on the individual's own media connections. Through the students' cross-generational research, their personal media histories are connected to an extended timespan. From this perspective, the meaning of media goes beyond practical function, and becomes more a matter of social practices and identity work.

The present article aims to explore how upper secondary students reflect on their identity, and on the media as a constraining and enabling factor in their social practice. A case study of a class with 27 students attending Vg3 ${ }^{1}$ General Studies in Media and Communication in an upper secondary school in Norway forms the basis of the discussion. Mediagraphy was implemented as a learning activity for the first time at an educational level other than tertiary education. The key research questions are:

What characterizes upper secondary students' reflections on their identity during their work with mediagraphy, and how do they depict the media as an agentive factor in their social practice?

\section{Mediagraphy as a Learning Activity}

Vettenranta (2010a, 2010b) developed Rantanen's (2005) global mediagraphy into a teaching method with master's degree students. The aim was to understand the connections between globalization, identity and the media. Vettenranta shows how Rantanen's mediagraphy table (Table 1) - consisting of different globalization factors, such as sense of identity, media use and experiences, lifestyle and education - became a framework for understanding how individuals have experienced globalization across cultures, generations and locations. Vettenranta claims that the students gained insight into media developments and the globalization process on the societal macro-level and individual experiences and media practices on the micro-level. Moreover, they learned about their identity in terms of being able to identify how the media has played an essential role in their life conduct, social practice and communication. One of the most significant pedagogical implications is that the students exercised and developed competencies such as self-reflection and evaluation (Vettenranta 2010b). The latter point is supported by findings from the present study (Schofield 2014).

We seek to investigate whether mediagraphy can also provide knowledge of how identities are constructed by and through a number of factors in individuals' social, cultural, historical and, especially, media-related contexts. We aim to discover whether the students gain insights into differences and similarities between generations and individuals in their family, and see changes and stability over time. As globalization is not a key issue for the present analysis, the learning activity is simply referred here to as "mediagraphy".

In the following, we will, in the context of media education and media literacy, apply an analytical approach to how identity and narratives are connected. 


\section{Identity and the Media}

From a cultural studies perspective, the concept of identity is strategic and positional, not essentialist, nor does it refer to the stable core of the self. On the contrary, it is fragmented and fractured, "constructed across different, often intersecting and antagonistic, discourses, practices and positions" (Hall 1996:4). Identity arises from the narrativization of the self, but this formation has some practical dilemmas when people navigate their identity narratives. From a sociocultural perspective, Bamberg (2011:6) argues that any claim of identity faces three dilemmas. One has to:

(1) Constantly navigate between continuity and change. The starting point of mediagraphy is not only an individual's own media relations but also the social life of different generations and their relations to the media. Mediagraphy then can be a basis for students to understand the changes in media use and the meaning of the media in the lives of older generations, but also what is consistent over time.

(2) Deal with a concurrent connection between sameness and difference (between self and other). The comparison between oneself and others comes into play both when the students research other individuals and when they discuss findings in the classroom context. Potentially the students will be able to identify traits that are similar to other people while also seeing what is unique in themselves.

(3) Manage the reciprocal connection between agency as "person-to-world" and as "world-to-person". Agency can be seen as a crucial notion for understanding the active engagement and control actors have in different contexts; the way people understand their past, future and present makes a difference for how they act (Emirbayer \& Mische 1998). According to Emirbayer and Mische (1998), agency is constructed temporally as actors engage in different structural environments, and is both reproduced and transformed through habit, imagination and judgment in interactive response to the various problems related to changing historical situations.

From our point of view, agency is an essential aspect of identity, but nevertheless inextricably linked to social and cultural contexts (see Ahearn 2001; Holland, Lachicotte Jr., Skinner, \& Cain 1998; Wertsch, Tulviste, \& Hagstrom 1993). Biesta and Tedder (2007:6) argue that people in certain sociocultural situations actually "shape their orientations", and thus "exert" their agency. In other words, agency is something that is possible to achieve, and hence learn and develop. To create a narrative, one uses sets of cultural tools, resources and relationships that can help in the development of agentive identities (Hull \& Katz 2006; Ochs \& Capps 1996). In this light, narratives can potentially create coherence from fragmented experiences, place the narrator in time and space and, not least, contribute to self-understanding.

\section{Context of the Study}

The article is based on an empirical case study conducted in a classroom setting. Mediagraphy was implemented as a learning activity in a class of 27 students attending the Vg3 General Studies Programme in Media and Communication in an upper secondary school in Norway. The project was conducted over the course of five weeks, five to ten lessons per week, in October/November 2011. Elisabeth, the teacher, mainly led the class 
project while the first author, as the field researcher, assumed the role of a participant observer. Additionally, he was an advisor for Elisabeth, as she had no practical experience of mediagraphy prior to this project.

The class consisted of 14 girls and 13 boys of Norwegian citizenship and ethnicity. In January/February 2012, 13 students, seven boys and six girls, were selected for interviews. They were selected with a view to obtaining a broad insight into student types, quality of student products and work effort levels. The school primarily offers programmes for specialization in general studies, but also creative education programmes such as Media and Communication.

In the Media and Communication programme in Norway, most of the classes during the first two years are related to practical, creative media use and production. Erstad, Gilje, and de Lange (2007:8) describe these students as "heavy consumers" of media, particularly the Internet, and most of them as relatively experienced media producers. As such, this education programme potentially offers a unique case for studying the interplay between media development, media use and identity. As we see it, the main objective of the programme is to enhance students' media literacy skills. For example, a key goal in the curriculum for the common core subject at the Vg3 level is that students should be able to "evaluate the media as a socializing factor and the media's ability to influence individuals and society" (Udir 2008:2).

\section{Method}

Here, we mainly focus on data from student products and interviews. The student products, called "mediagraphy essays", are responses to a school assignment, but as they are also based on reflections on actual experiences in the lives of the students and their families, they resemble life stories, or personal, self-reflective and subjective narratives (Almås \& Gullestad 1990). According to several social scientists, life stories can be important data for studying the complex dualistic relations between the self and the social context (Giddens 1991; Goodson 2000; Harrison 2009). The interviews are semi-structured and "focused", which, according to Kvale and Brinkmann (2009), is a narrower version of the in-depth interview. In this case, we created an interview guide based on a tentative analysis of observations and student products.

We zoom in on mediated action when analysing the data. Wertsch (1998) argues that this is the most informative unit of analysis in sociocultural research. Mediated action is a real-time action where mediational means, social actors and the sociocultural environment intersect. Wertsch (1998) claims that all human actions are mediated through such cultural tools as everyday objects, technologies, social institutions and so on. In the present study, this will apply to the student products as actions taking place between the students and the learning activity of mediagraphy. The interviews are seen as a mediated action where the interviewer (the first author) and the students are social actors in a particular meaning-making context, i.e. the interviews are not seen as a means of grasping "true experience".

In the analysis process, some aspects emerged as more relevant than others and "opened up the field". In turn, certain theories and concepts enhanced our understanding of the phenomena that the case study revealed. Such an approach is characteristic of analytical induction (Erickson 2012). We coded the material according to themes 
before tentative assertions were framed, after which emerging research questions and interpretations of the data became apparent. Progressively, common themes were recognized that developed into analytical categories. The qualitative software NVivo 9/10 aided in the practical coding process.

Several essays contained other modalities than the written word, for example images, graphics and illustrations. Multimodal texts involve several sign systems and thus an increased meaning potential (Kress 2003). In our analysis, we turn to Bauman and Brigg's (1990) tangible analytical concepts. They argue that authors exercise agency when they compose various types of text. If, for example, images are used in a montage, they are decontextualized from their original context and recontextualized as a reflective process. In other words, the use of images is not merely a detached representation but also a new reflection and meaning-making. Meaning from the original context is still present, but the text must be interpreted as a new form with new functions and meaning (Hull \& Katz 2006).

\section{Epistemology and Mediagraphy}

Important epistemological issues are raised when students are asked to conduct their own research. In many ways the balance of power in the classroom is put to the test - the students become agents who co-construct the concept of knowledge in interaction with the teachers, the researcher, the teaching material and teaching methods. As such, the present study rests on a social constructionist concept of knowledge (see e.g. Delanty $\&$ Strydom 2003), and focuses on the students' meaning-making as an active process in social practices. Different types of information do not have intrinsic meaning, but rather have "meaning potential" that is open to interpretation (Linell 2009). Knowledge is thus not generated in isolation by the teacher or any other actor, but is created in the interaction between different actors and is highly contextually dependent.

Individuals' narratives are at the centre of the students' research. Although the ideal in modern science has been absolute, objective knowledge, it has in recent decades gradually become more accepted to draw on people's stories as representations of social reality and as a form of knowledge (Bruner 1991; Johansson 2005). The most important aspect of the data collected by the students is, in this light, not their potential status as "facts". The data can however contribute to insight into how social reality is constructed, and to broadening the students' existing understandings of different phenomena.

\section{The Student Assignment}

The practical student assignment was to research individuals from four generations on one side of their own family, including the students themselves, with respect to different events and experiences in their lives. Rantanen's mediagraphy table (Table 1) was used for the data collection; it conceptualizes a number of factors in four individuals' lives and puts them in relation to each other. The data were then analysed in light of today's media society and the students' everyday media experiences.

The teacher introduced the theory and concepts before the students started their data collection, where qualitative interviews were the main method. Whenever possible, the students used primary sources, but when family members had died or were difficult to 
Table 1. Mediagraphy table (adapted from Rantanen 2005)

\begin{tabular}{|l|l|l|l|l|}
\hline & $\begin{array}{c}\text { Great-grandmother/ } \\
\text { Grandfather }\end{array}$ & $\begin{array}{c}\text { Grandmother/ } \\
\text { grandfather }\end{array}$ & $\begin{array}{c}\text { Father/ } \\
\text { mother }\end{array}$ & $\begin{array}{c}\text { Son/Daughter } \\
\text { (the student) }\end{array}$ \\
\hline Profession & & & & \\
\hline Home country & & & & \\
\hline Place & & & & \\
\hline Time & & & & \\
\hline Changes in lifestyle & & & & \\
\hline Education & & & & \\
\hline Changes in class & & & & \\
\hline Family & & & & \\
\hline Travel & & & & \\
\hline First journey abroad & & & & \\
\hline Languages spoken & & & & \\
\hline Media and communication & & & & \\
\hline Global media event & & & & \\
\hline Interests & & & & \\
\hline Ideology & & & & \\
\hline Resistance to & & & \\
\hline Identity & & & \\
\hline
\end{tabular}

contact, secondary sources were important. Some students used additional material, such as photo albums, videos or parish records. The students developed a research question, undertook an analysis and wrote an interpretative mediagraphy essay. An assignment guide that proposed a structure for the essay aided the students. The students were expected to make use of their textbooks and supplementary sources to employ subject theories and terminology. Length was set at around 1500-2500 words.

\section{Martha and Frank: Two Students as Examples}

We focus our analysis on two students' essays and interviews. They do not constitute a representative selection of the class, but illustrate different ways of approaching the mediagraphy project and ways of making sense of the topic. We intend to use Martha's and Frank's examples to present a rich exploration of the types of reflections and narratives produced during the project. A broad analysis of the data from the whole class creates an imperative background for the discussion that follows.

Martha solved the task by adhering quite closely to the teacher's suggestions. In the interview, she states that she has an "instinct-like" approach to school tasks, in the sense that she wants to achieve good results in school and that she generally makes a great effort. Frank's process has a different point of departure. Frank explicitly stated in the interview that initially he was opposed to the task, and displayed overt resistance during the project. Observational data show that he went through a process of change involving a somewhat unexpected turn, as it seems he was one of the students with the most pronounced learning outcomes. Moreover, Frank's case sheds light on other ways of making sense of identity and different kinds of expression than in Martha's case. 


\section{Martha's Mediagraphy: Mediated Social Practices and Physical Activity}

Martha's mediagraphy essay addresses how her family members' social practices have changed in step with general developments in society and in the media in particular. She reviews her family members' biographies relatively thoroughly before comparing the generations and reflecting on differences and similarities. Martha has not been able to go further back than to her grandfather as it was difficult to find information on her great-grandparents' generation. She writes about a family that has lived relatively stable lives, and the generations have largely been settled in the same region of the country. Martha's essay stretches back to the forties, and thus media history, from the radio era to the Internet age, has a central place.

From media history through the family's media relations Martha turns to her concern to the decline in physical activity among young people today, herself included. In her eyes, this development is due to the media-dominated everyday lives young people lead. How time is spent seems to be an important issue for many of the students in this class. Several students turn to self-reflection and "see" that they spend a lot of time in and through the media - social media in particular, which has become one of the main ways to communicate and socialize, contrary to previous generations. This finding is hardly surprising, as most students probably are well aware of the trend towards more intensive media use in the Western world. What is perhaps special here is the articulation of the life experiences that they encountered. This made it possible to compare with other individuals in other generations, which seems to facilitate reflections on what the differences and similarities actually consist of, and how quickly the changes have manifested themselves in social and cultural patterns. The excerpt below illustrates how Martha expresses some of the differences between herself and her mother.

\section{Martha: Excerpt 1}

I see a clear difference between me and my mother. Mum had one Barbie doll as a child, no TV, no Internet and no mobile phone with games. She had to get out of the house to entertain herself, and often she ended up with bumps, fractures or sprains. [...] I, on the other hand, who grew up in the nineties and early two thousands, never hurt myself besides some slivers and bruises. I think this is because I have had more access to indoor entertainment. First and foremost, I had a lot more toys because mom and dad were working and earned good money. Later I was also allowed to play video games on Dad's mac.

When Martha reflects on differences and similarities between herself and others (here primarily her mother), she is orienting herself to Bamberg's dilemmas (1) and (2). She navigates between continuity and change, not only between generations but also in herself in the media-saturated world. In fact, her essay emphasizes reflection on how she has undergone change at the same time as she "is herself". Dilemma 3, the agency dilemma, arises when Martha addresses access to media, toys and leisure. She writes about "being allowed" to play video games, and touches on the question of who decides over her media use, indicating that special rules apply to computer gaming. As Bamberg (2011) writes, the question of agency begins by asking whether "I" construct the world as it is or if "me" is constructed by the world. From the perspective of media education, 
this is usually a question of "media effects" in the individual's life, and media use within families involves continuous negotiation over use and time spent with the media. But as we see, this is also a question of agency and identity.

In Excerpt 2, Martha reflects on her own actual use of media and how her media use constrains and enables social actions. While her mother did not have any easy or convenient access to modern media during her childhood, Martha's early years and her present are both characterized and dominated by a wide range of different types of media.

\section{Martha: Excerpt 2}

When it comes to media use, I use my computer and the Internet a lot, TV and iPod for music, and of course my mobile phone, which is most important. I've become addicted to Facebook, which I feel is necessary to keep up with my group of friends, and I can't leave the house without my mobile phone. I use TV mostly for watching entertainment programmes and movies, but lately my interest in news has grown. I've also started reading newspapers, but mainly read the comic strips. I prefer reading news on Internet newspapers, as the articles there are shorter and more to the point.

Martha has many reference points to different types of media use, and her narrative comprises broad and extensive media use. A recurring issue is precisely how her life is framed and partially structured by her media use, and thus by developments within technology and in the media world. On the one hand, Martha writes about media use limiting her leisure activities and social actions; on the other, her media use opens up a wide range of opportunities for social practice, learning, communication and so on. Media use is hence portrayed both as a powerful facilitator for and as a constraint on Martha's sense of agency, so these reflections are accounts of how Martha experiences the dilemma of being an agent. Martha depicts the Internet as something that has opened her eyes to new interests and also as a space where she can develop and maintain a variety of interests. At the same time, our interpretation is that Martha is concerned that her interests outside the media world have lost ground compared to technology-mediated experiences. In the discussion section, Martha elaborates on this by comparing findings from the different generations:

\section{Martha: Excerpt 3}

In the forties, people didn't have anything but radio and newspapers. For extra enjoyment they went to the cinema in the city. At this time people were much more active than today. Children, for example, didn't sit in their rooms all day staring into a screen, they were outside playing [...]. Really this sounds like a much healthier childhood than what we see today, although it's difficult to do anything about it. [...] When the children's TV channels came to Norway many parents were relieved because their children could sit and watch cartoons while they could take a nap or get some work done in peace and quiet. [...] Today children have so much to occupy themselves with, and thus they can easily opt out of activities such as football, "hide and seek", tag, skipping rope and such, and rather choose to sit inside playing with toys, playing computer games, or watching cartoons. 
The agency dilemma is an overarching theme here, as Martha describes how our social practices to some extent are constrained by such factors as media use or our financial situation, factors that also give us options for social action. Thus, for Martha, everyday media use and media developments have powerful influences on how she is able to conduct her life, in combination with other sociocultural trends, such as economic growth in Norway, and technological advances that have given children and young people more toys, more technical appliances and more recreational activities. In Excerpt 4, Martha is concerned with the consequences of the media on a societal, global level.

\section{Martha: Excerpt 4}

Another negative point about the media's enormous development is that most people are not as socially active as they used to be before. [...] Today everything that is social happens through Facebook, the largest social media we have. [...] The development within the media might be contributing to the growing obesity problem we are facing today. Obese children were a rarity in the forties, but today, with the mass production of unhealthy food and the growing "sofa lifestyle", overweight children are becoming more and more common.

Martha identifies traits both on an individual level, which in some way constrains her present in a quite direct way, and on a macro-level, which also sets limits on her sense of agency, however, in a more implicit, subtle way.

\section{Martha's Process}

Martha evaluates the significance of the project in her interview. She expresses that the process of conducting research through interviewing family members meant acquiring a new type of understanding of both her present life and the past, but also her future.

It's actually kind of important to remember that things were not that easy before, like they are now. 'Cause I have an iPhone that I can use for taking pictures and for going on the Internet and everything is possible, really, anytime. [...] it's like history, right - it's important that we know our history so that we're able to develop further, and so that we're able to avoid mistakes being made again. [...] It's not until now I sort of see how helpful these texts really are, because the more we write down and think about history and think about where we are now, the more we come to understand it later. [...] And I think that's very important.

As we see, Martha argues that her findings are important for her now, but also for future choices and challenges. We interpret that the mediagraphy project has had actual value for her because it revolves around her on a personal level, and makes her media relations explicit for her. The theory she used and the analysis she conducted also connect these personal discoveries to something general. 


\section{Frank's Mediagraphy: Nationality, Identity, Globalization and Social Media}

Frank's essay does not follow the structure given by the teacher, and the genre in which he writes is both more critical and ironic than the genre chosen by most of the class. His writing style is compact and he expresses himself using concise sentences. Although the students were expected to gather information from four generations, Frank has only interviewed his father and he has not filled in the mediagraphy table. Nonetheless, he makes reflections based on the lives of several generations. The essay deals with nationality, identity and globalization, discussing how these aspects are changing in step with the changes in how people use and communicate through the media, social media in particular. He draws on sources from the specific project and other subjects, as well as from Internet sources. Frank's headline is an open, but yet somehow critical and curiosity-provoking question: "Where did our sense of nationality go?"

The starting point for Frank's text is an account of his understanding of the causes and consequences of the globalization process. He recognizes a number of social, historical and cultural aspects as influencing factors for who we are and how we conduct our lives, but he primarily elaborates on the media that surround us nowadays. He wonders about what has happened to our identity and sense of belonging, and specifically our national identity. He defines his identity as a "rebel", and both in the essay and in the interview he explicitly expresses that he wants to stand out from the crowd. An excerpt from his essay illustrates this:

\section{Frank: Excerpt 1}

Change in lifestyle from the teenage years to adulthood: Recently I moved to my own apartment. Student, I want higher education. [...] Addicted to the Internet, active on social media, web designer and developer. I am somewhat politically active, liberal; I want a free flow of information and to reject censorship. [...] Identity: Rebel, tired of doing as others.

It seems that Frank refers to himself in this way (as a rebel) after seeing his life story juxtaposed to the previous generations of the family, and also by reflecting on his individual development and experiences. He argues that a clear difference has manifested itself between today's youth and other generations, focusing on identity, as many young people do not see themselves as particularly "Norwegian". Bamberg's (2011) second dilemma is touched upon in this reflection, dealing with similarities and differences between oneself and others: the self is constructed in the narration in opposition to others. The first dilemma concerning continuity and change is a concrete focal point for Frank's reflections, as he considers himself a person who has felt a persistent resistance to being the "typical" Norwegian. He writes for instance that he never quite has identified with Norway's national day (17 May), not even as a child, and that this feeling has intensified in step with cultural disintegration and media development. Frank writes that he does not experience himself as typically Norwegian, and portrays a general development among adolescents in which national identity has undergone profound change. In this way, he depicts identity aspects he recognizes in others, and likewise aspects he does not want to acknowledge. In his ironic style Frank writes: 


\section{Frank: Excerpt 2}

$[\ldots]$ the younger generation [...] losing their sense of nationality and don't feel particularly typically Norwegian - for what is it really, being a typical Norwegian? The sense of nationality less than 200 years ago was sky high; Norwegians were the best, no protest. When we sat on the mountaintop and looked out over the fjord, opened a packed lunch with sandwiches and cheese, then there was no one else who could match us.

\section{Multimodal Expressions - Ambiguous Reflections}

What is lost with Frank's economical form of expression is gained in his use of images and metaphors. He inserts three classic Norwegian paintings in his product, all three of which can reveal analytical clues to help us understand Frank's reflections and ways of thinking. As such, a closer look at Frank's use of images can give some interesting insights into the identity work Frank is actually doing in his essay. As we interpret his use of the images, Frank associates them with the traditional or historic Norwegian national identity. Additionally, this says something about what Frank distances himself from, what he is not - or what is not part of his identity (cf. Dilemma 2).

\section{Image 1. The Adventures of the Ash Lad (Kittelsen 1900)}

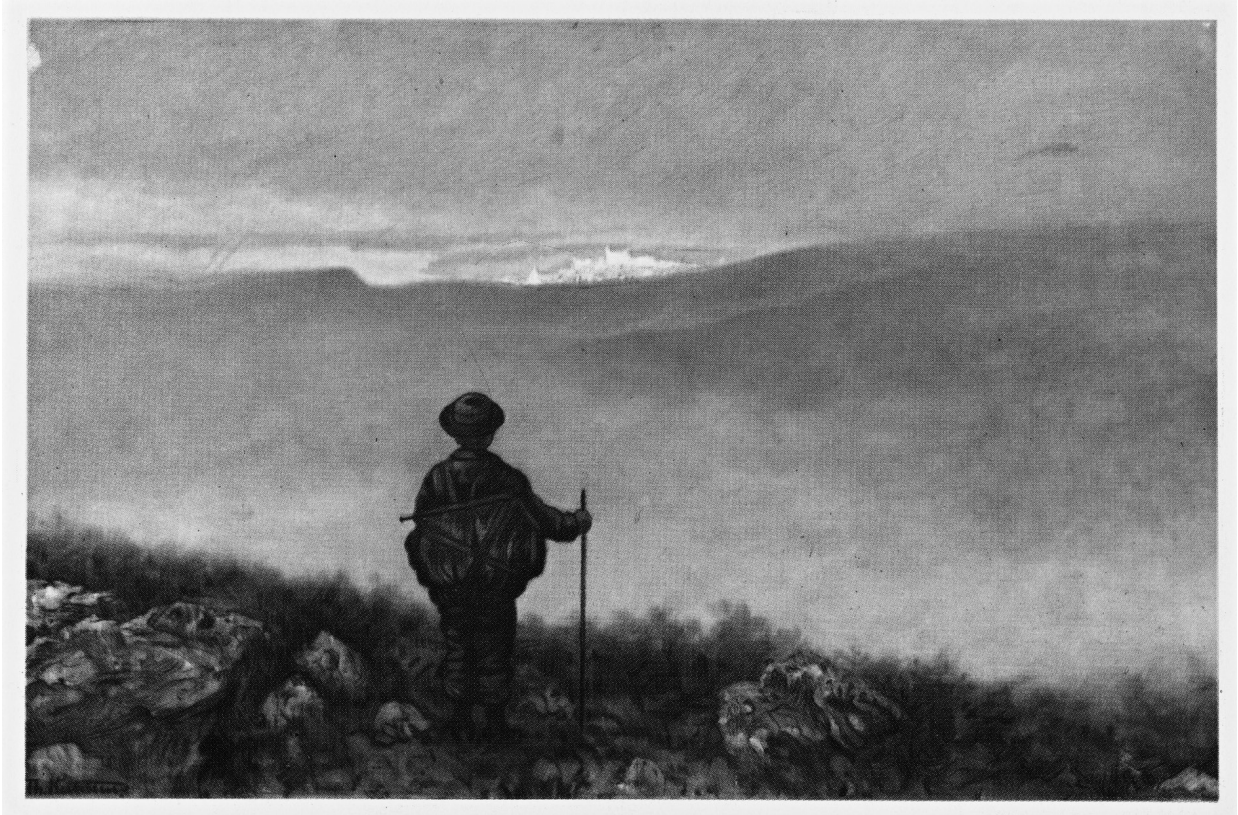

In a section called "Me in relation to globalization", Frank uses a traditional work in Norwegian art history; "Askeladdens eventyr" ("The Adventures of the Ash Lad") by Th. Kittelsen (1900). The picture was originally an illustration for a folk tale collected and written down by Asbjørnsen and Moe, depicting a young man travelling to a faraway shimmering castle, "Soria Moria". The Ash Lad can be said to have significant symbolic value for Norwegian identity as a straightforward, fortunate and charismatic young man 
Image 2. The Birkebeiners (Bergslien 1869)

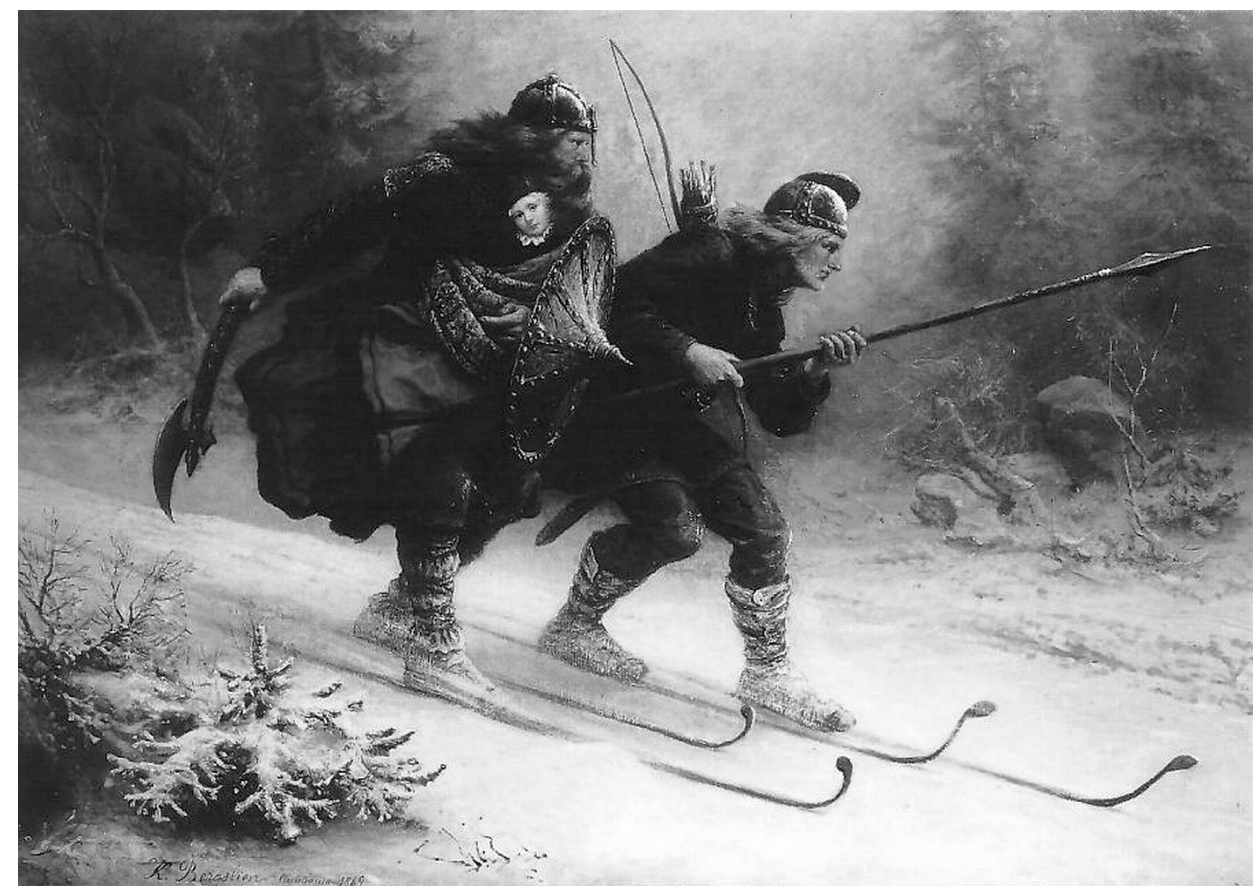

who overcomes all obstacles and eventually wins. Image 2 shows the painting "Birkebeinerne" by Knud Bergslien (1869). The Birkebeiners were a rebellious people, but also a political party. Nowadays the Birkebeiners are mostly associated with a traditional long-distance cross-country race in Norway, and our interpretation is that this image represents what Frank thinks of as being typically Norwegian. Frank uses both images in his product without reference, but apparently gives them implicit meaning in the text. Frank has decontextualized the images from their original context and recontextualized them in his reflective process (cf. Bauman \& Briggs 1990). His use of images represents the creation of a new reflection and meaning-making; it is not merely a detached representation. His montage contains some of the paintings' original meaning, which tells of the traditional Norwegian, about the folk tales and legends that many of the Norwegian national narratives are based on. But when used in Frank's ironic and argumentative text, new meaning concerning Frank's identity is applied - his resistance to the classical Norwegian image and his defence of the new generation.

\section{Frank's Process}

Martha is quite explicit when it comes to learning outcomes, while Frank's thoughts on this are more implicit. Nonetheless, he also considers the project to be significant. He expresses in his interview that during the project he developed a personal viewpoint on the issues he wrote about, and that the project in some sense "forced" him to take a position on the information and knowledge he encountered in the process. Frank handed in his paper past the deadline and it was not completed; but Frank did not "stress" about it, as he expressed it. For Frank, this approach meant that he had time to make up his 
mind about the findings, and that he could orient himself and process all the "facts" and information. He states that:

Well, I wasn't really that... certain... when I talked about my identity until I had gone through it and gotten involved in it through this assignment. It's only after the task it has become something that I... bring up and that I'm really interested in.

Frank seems to have come to a turning point during the process. He was initially critical, also to what types of outcomes could be expected from such personal research methods as mediagraphy. But, as Frank says in the interview, he eventually became fascinated by the topics he wrote about and also benefitted from this after the project, referring to the identity concept in projects in other subjects.

\section{Discussion}

Through Martha's and Frank's examples, we have seen how the students' reflections in the mediagraphy project encompass identity and media use. It seems as though mediagraphy constitutes both a means of sorting the data they found in their own research and a work method that nurtured certain types of reflection. In the discussion, we will look into what these reflections might have meant for the students.

In general it seems that the three identity dilemmas (cf. Bamberg 2011) are interdependent. The comparison with other individuals in other times and spaces is an important component of the types of reflection that were made in the mediagraphy essays. Martha's essay examines how her generation's media use has brought about a huge increase in social and cultural opportunities, on the one hand, and problems related to physical activity and social practice, on the other. Frank focuses on identity and changes in who we are and where we belong. Through the different generations, the students could capture individual experiences at different times and in different spaces as well as development over a time span of several decades, for some students even up to a hundred years. The students see that the development over time is connected to the lives of the other generations in their families.

Moreover, the work with mediagraphy involves self-reflection and introspective contemplation over one's own choices, values and other identity-related aspects. In our interpretation, the mediagraphy essays can be identity representations (Potter 2012). Through media production and the recontextualizing of media content, identity can be represented in more complex ways than in traditional forms - with the student in control. As we see it, in this way mediagraphy provides the opportunity to tell one's own history in one's own voice, using various media resources and materials. Furthermore, beyond the representation of an identity, students construct and reconstruct their identity through working with mediagraphy.

The social, cultural and historical analysis implied in the mediagraphy method is closely related to the agency dilemma. As such, mediagraphy can scaffold the students' reflections on their own sense of agency. As Martha's and Frank's essays imply, the question of how contextual factors constrain but also facilitate various social practices is a dilemma that is at the core of what identity is about. This dilemma involves asking who constructs the perceived world as it is, is it I as a person or is me being constructed by the world, and in this case especially by the media saturated world and "within [...] 
representation" (Hall 1996:4). The students express that they have control over their own actions and choices, but at the same time they write and talk about contextual factors that both curtail and augment their social practice. Media use emerges as the single most important factor in this respect. This applies for instance to which arenas they communicate on, how they spend their time, what job and educational opportunities they envisage and ultimately how they perceive themselves, the community and the world.

It seems as if the data collected by the students have traits of the type of knowledge pointed out by Johansson (2005); people's narratives can give insights into how general societal phenomena have, and have had, meaning in individual lives. Such knowledge is necessarily subjective and is mediated in the interaction between different actors in various contexts. The group of informants in the present study is composed of media students with extensive media use, who are relatively well acquainted with various aspects of the media. There is reason to question the extent to which findings from these informants can be generalized. In our view, the types of experiences mediated by the mediagraphy can help students to reflect on their media use and relations. As a method, it raises questions relevant for further discussion with others and in this way also helps to build knowledge collaboratively. As such, we argue that the method will be of value also when applied in student groups that are different from this particular group with regard to, e.g., demographic, ethnic, and socioeconomic background.

We find that, as a learning method in media education, mediagraphy is a type of identity work in which aspects of identity are exemplified through individual experiences and media relations over generations. Furthermore, we claim that mediagraphy can contribute to one's understanding and interpretation of one's own identity. In this way, the agency dilemma - the dilemma most directly connected to action - is a central element. Thus, we find that mediagraphy can play a role in exerting an agentive identity, which we believe is an important contribution in a time of insecurity, with rapidly shifting social and cultural conditions and increasing media density.

\section{Note}

1. VG3 is the third and final year of the upper secondary school and qualifies students for further education.

\section{References}

Ahearn, L. M. (2001). Language and Agency. Annual Review of Anthropology, 30:109-137.

Almås, R., \& Gullestad, M. (1990). Livshistorier: seks bidrag til selvbiografikonkurransen "Skriv ditt liv" (Life Stories: Six Contributions to the Autobiography Contest "Write Your Life"). Oslo: Universitetsforlaget.

Bamberg, M. (2011). Who am I? Narration and its contribution to self and identity. Theory \& Psychology, 21(3):3-24.

Bauman, R., \& Briggs, C. L. (1990). Poetics and Performance as Critical Perspectives on Language and Social Life. Annual Review of Anthropology, 19:59-88.

Bergslien, K. (1869). Birkebeinerne fører Haakon Haakonson som barn til Trondheim (the Birkebeiners lead Haakon Håkonson as a child to Trondheim) Retrieved 29/4, 2013, from http://www.nnkm.no/ kunstverk_i_fokus Birk.htm

Biesta, G., \& Tedder, M. (2007). Agency and learning in the lifecourse: Towards an ecological perspective. Studies in the Education of Adults, 39(2):132-149.

Bruner, J. S. (1991). The Narrative Construction of Reality. Critical Inquiry, 18(1):1-21.

Buckingham, D. (2007). Digital Media Literacies: Rethinking Media Education in the Age of the Internet. Research in Comparative and International Education, 2(1):43-55. 
Burn, A., \& Durran, J. (2007). Media literacy in schools: practice, production and progression. London: Paul Chapman.

Delanty, G., \& Strydom, P. (2003). Philosophies of social science: the classic and contemporary readings. Maidenhead: Open University Press.

Emirbayer, M., \& Mische, A. (1998). What is Agency? American Journal of Sociology, 103(4):962-1023.

Erickson, F. (2012). Qualitative Research Methods for Science Education. In B. J. Fraser, K. G. Tobin \& J. M. Campbell (Eds.), Second International Handbook of Science Education. Dordrecht: Springer Netherlands.

Erstad, O., Gilje, Ø., \& de Lange, T. (2007). Morgendagens medieprodusenter. Om mediefagselevers produksjonspraksiser $i$ videregående skole (Tomorrow's Media Producers. About Media Students' Production Practices in Upper Secondary School). Oslo: Unipub.

Gauntlett, D. (2007). Creative Explorations. New approaches to identities and audiences. London: Routledge.

Giddens, A. (1991). Modernity and self-identity: self and society in the late modern age. Cambridge: Polity Press.

Goodson, I. F. (2000). Livshistorier: kilde til forståelse av utdanning (Life stories: source to understanding education). Bergen: Fagbokforl.

Hall, S. (1996). Introduction: who needs "identity"? In S. Hall \& P. Gay (Eds.), Questions of cultural identity (1-17). London: Sage.

Harrison, B. (2009). Editor's Introduction: Researching Lives and the Lived Experience. In B. Harrison (Ed.), Life History Research (Vol. 1:xxiii-xlviii). London: Sage.

Holland, D., Lachicotte Jr., W., Skinner, D., \& Cain, C. (1998). Identity and Agency in Cultural Worlds. Cambridge, Massachusetts; London, England: Harvard University Press.

Hull, G. A., \& Katz, M.-L. (2006). Crafting an Agentive Self: Case Studies of Digital Storytelling. Research in the Teaching of English, 41(1):43-81.

Jenkins, H. (2007). Confronting the Challenges of Participatory Culture - Media Education for the 21st Century (Part Two). Digital kompetanse, 2(2):97-113.

Johansson, A. (2005). Narrativ teori och metod: med livsberättelsen i fokus. Lund: Studentlitteratur.

Kittelsen, T. (1900). Askeladdens eventyr (Soria Moria) (The Adventures of the Ash Lad) Retrieved 25/4, 2013, from http://www.flickr.com/search/?w=48220291@N04\&q=kittelsen

Kress, G. (2003). Literacy in the new media age. London: Routledge.

Kvale, S., \& Brinkmann, S. (2009). Interviews: learning the craft of qualitative research interviewing. Los Angeles, Calif.: Sage.

Kaare, B. H. (2008). Youth as Producers. Digital Stories of Faith and Life. Nordicom Review, 29(2):193-204.

Lankshear, C., \& Knobel, M. (2007). Sampling "the New” in New Literacies. In M. Knobel \& C. Lankshear (Eds.), A New Literacies Sampler (1-24). New York: Peter Lang.

Linell, P. (2009). Rethinking language, mind, and world dialogically: interactional and contextual theories of human sense-making. Charlotte, N.C.: Information Age Publ.

Ochs, E., \& Capps, L. (1996). Narrating the Self. Annual Review of Anthropology, 25:19-43.

Potter, J. (2012). Digital media and learner identity: the new curatorship. Basingstoke: Palgrave Macmillan. Rantanen, T. (2005). The media and globalization. London: Sage.

Schofield, D. (2014). Young People Exploring Their Media Experiences - Mediagraphy as a Reflection Tool in Upper Secondary School. Nordic Journal of Digital Literacy, 9(2):112-127.

Udir. (2008). Programområde for studieforberedende vg3 innen medier og kommunikasjon. Lareplan i felles programfag medier og kommunikasjon (Programme Area for Vg3 General Studies in media and communications. Curriculum for common programme Media and Communication) Retrieved 10/6, 2013, from http://www.udir.no/k106/MED4-01/Hele/

Vettenranta, S. (2010a). Global Mediagraphy. A Teaching Method in Media Education. In S. Kotilainen and S.-B. Arnolds-Granlund (Eds.), Media Literacy Education. Nordic Perspectives (167-180). Göteborg: Nordicom.

Vettenranta, S. (2010b). Mediegrafi: en metode for å forske på og å undervise i globalisering (Mediagraphy: a Method for Researching and Teaching Globalization). Oslo: Gyldendal akademisk.

Wertsch, J. V. (1998). Mind as action. New York: Oxford University Press.

Wertsch, J. V., Tulviste, P., \& Hagstrom, F. (1993). A Sociocultural Approach to Agency. In E. A. Forman, N. Minick \& C. A. Stone (Eds.), Contexts for Learning: Sociocultural Dynamics in Children's Development (336-356). New York: Oxford University Press.

Daniel Schofield, Ph.D. Candidate, Department of Education, Norwegian University of Science and Technology (NTNU), Trondheim, daniel.schofield@svt.ntnu.no

Reijo Kupiainen, Ph.D., Adjunct Professor of Media Education, Department of Education, Norwegian University of Science and Technology (NTNU) / University Lecturer, School of Education, University of Tampere 